\title{
Mortality Rate of Heterobranchus bidorsalis fingerlings Exposed to Cassava Mill Effluents
}

\author{
Enetimi Idah Seiyaboh and Sylvester Chibueze Izah* \\ Department of Biological Sciences, Niger Delta University, Nigeria \\ Submission: August 14, 2018; Published: October 16, 2018
}

"Corresponding author: Sylvester Chibueze Izah, Department of Biological Sciences, Niger Delta University, Wilberforce Island, Bayelsa State, Nigeria, Tel: +234 7030192 466, Email: chivestizah@gmail.com

\begin{abstract}
Cassava mill effluent is toxic to the ecosystem and its associated biota. This study evaluated the toxicity of cassava mill effluents against fingerlings of Heterobranchus bidorsalis. The fishes with mean length $4.00 \mathrm{~cm}$ fish were allowed to acclimatize in the laboratory for 7 days. Range finding test was carried out at four varying concentrations. Based on the result of the range finding test the main experiment was carried out at $0.000 \mathrm{ml} / \mathrm{L}, 0.003 \mathrm{ml} / \mathrm{L}, 0.006 \mathrm{ml} / \mathrm{L}, 0.012 \mathrm{ml} / \mathrm{L}$ and $0.015 \mathrm{ml} / \mathrm{L}$. The mortality rate was dose dependent, which showed a significant decline as concentration increased. At 96 hours the mortality rate were $39.55 \%, 50.00 \%, 75.00 \%$ and $91.68 \%$ for $0.000 \mathrm{ml} / \mathrm{L}, 0.003 \mathrm{ml} / \mathrm{L}, 0.006 \mathrm{ml} / \mathrm{L}$, $0.012 \mathrm{ml} / \mathrm{L}$ and $0.015 \mathrm{ml} / \mathrm{L}$ respectively. This suggests that cassava mill effluents in aquatic ecosystem could adversely affect the health of fishes as well as their distribution and abundance in their ecosystem. Therefore, caution should be exercise during dewatering processes in cassava mills close to surface water.
\end{abstract}

Keywords: Aquatic ecosystem; Cassava mill effluents; Fishes; Mortality and Toxicity

\section{Introduction}

Nigeria is the leading cassava producing nation accounting for over20\% of the global output [1-15]. Cassava is a major staple tuber crop in Nigeria and many other African countries especially in western region. Cassava has several industrial, food and feed applications. Over $60 \%$ of total cassava tuber produced in Nigeria is used for the production of gari (fermented cassava flake). While the remaining $40 \%$ is used for the production of fufu, lafun, animal feeds and other industrial purposes such as adhesives, etc.

Cassava processing enterprise is dominated by smallholder especially in the Niger Delta region of Nigeria. During gari production from cassava tuber large amount of waste water is generated during the dewatering stage [13]. In many rural communities in the Niger Delta region of Nigeria, the effluents generated during cassava processing are discharged into the environment without treatment [4-5]. The effluents may drain to the nearby pit and/ or surface water.

In many coastal communities in the Niger Delta, cassava processing is carried out close to surface water resources. And during the wet season, the effluents often end up in the surface water due to the effect of runoff. The effluents are acidic in nature [16-17]. Hence there is the tendency of the effluents to cause acidification in the ecosystem [13] due to the acidic condition of the waste water [16-17]. Acidification of surface water resources tends to have short and long-term impacts on the species composition (fisheries, plankton, benthic organisms and macrophytes) of the ecosystem with regard to diversity and abundance [13]. In fishes, Izah et al. [13] reported that acidification of the aquatic ecosystem could lead to disease condition, egg damage, high mortality rate of oyster and species of crustaceans that are acid tolerant on short term basis. The authors furthermore reported that acidification could lead to loss of habitat and growth abnormalities, decline in spawning potential in long term.

Beside acidity, the quality of the cassava mill effluents can be measured based on physicochemical (odour, pH, salinity, electrical conductivity, turbidity, total suspended solids, total hardness, total alkalinity, cyanide, dissolved oxygen, chemical and biological oxygen demand, nitrate, nitrite, sulphate, calcium, sodium, magnesium, potassium, carbonates etc), heavy metals (iron, nickel, manganese, copper, lead, cadmium, zinc, chromium, lead, etc) and microbiological parameters (based on the density of coliforms, total heterotrophic bacteria, total fungi, lactic acid bacteria, lipolytic, cellulolytic, phosphate solubilizing and nitrifying bacteria) [13] .

Fishes (especially fin fish) are indicator organisms that are used during toxicological assessment of aquatic ecosystem. During toxicological studies, several parameters including enzymes, metabolites, electrolytes, haematological, histopathological and histology, behavioral response, organosomatic index and mortality rate are measured [13,18-32]. The toxicity of cassava mill effluents have been widely assessed based on mortality, behavioural response, enzyme, histopathological and haematological index using Clarias gariepinus as test organisms [30-36]. 
Heterobranchus bidorsalis is another fish species that is also used in toxicological studies especially in the Niger Delta region. Heterobranchus bidorsalis is majorly cultured in ponds (earthen and concrete) in many coastal communities in Bayelsa state. But information on toxicity effects of cassava mill effluents on Heterobranchus bidorsalis is scanty in literature. Therefore, this study assessed the mortality rate of Heterobranchus bidorsalis fingerlings exposed to cassava mill effluents.

\section{Materials and Methods}

\section{Fish Procurement and source of the cassava mill ef- fleunts}

A total of two hundred and sixty healthy fingerlings of Heterobranchus bidorsalis with mean length $4.00 \mathrm{~cm}$ were purchased from a private fish farm in Yenagoa metropolis, Bayelsa state. The fish samples were transported to the laboratory in 20liter rubber cans with their natural water. The cassava mill effluents used for the study were obtained from a small scale cassava processing mill in Ndemili, Delta state, Nigeria. The effluents were transported to the laboratory in an ice pack.

\section{Acclimation of the fish samples}

In the laboratory the fishes were allowed to acclimatize in circular rubber aquaria for 7 days. During the period, the fishes fed with their normal coupon fish diet. The test water was renewed daily. During the acclimatization period mortality rate were less than $1 \%$.

\section{Trial test}

During the trial test, $10 \mathrm{mls}, 30 \mathrm{mls}, 50 \mathrm{mls}$ and $70 \mathrm{mls}$ of the effluents were pipetted into 4litre of water in the aquarium. The effluents were renewed every 24 hours for 48 hours. This was carried out to determine the sub-lethal concentration for the main experimental run.

\section{Main experiment}

Six concentration of the effluents viz: $0.000 \mathrm{ml} / \mathrm{L}, 0.003 \mathrm{ml} / \mathrm{L}$, $0.006 \mathrm{ml} / \mathrm{L}, 0.009 \mathrm{ml} / \mathrm{L}, 0.0012 \mathrm{ml} / \mathrm{L}$ and $0.015 \mathrm{ml} / \mathrm{L}$ were made

Table1: Some in-situ parameters tested during the bioassay.

\begin{tabular}{|c|c|c|c|c|c|c|}
\hline Concentration, $\mathbf{m l} / \mathbf{L}$ & TDS, $\mathbf{m g} / \mathbf{L}$ & Temperature, ${ }^{\circ} \mathbf{C}$ & Salinity, $\mathbf{m g} / \mathbf{L}$ & Conductivity, $\boldsymbol{\mu S} / \mathbf{c m}$ & $\mathbf{p H}$ & Turbidity, NTU \\
\hline 0.000 & $22.77 \pm 0.25 \mathrm{a}$ & $28.30 \pm 0.26 \mathrm{a}$ & $16.13 \pm 0.15 \mathrm{a}$ & $32.43 \pm 0.25 \mathrm{a}$ & $7.03 \pm 0.06 \mathrm{f}$ & $0.42 \pm 0.11 \mathrm{a}$ \\
\hline 0.003 & $72.97 \pm 0.40 \mathrm{~b}$ & $28.33 \pm 0.21 \mathrm{a}$ & $46.20 \pm 0.20 \mathrm{~b}$ & $88.80 \pm 0.10 \mathrm{~b}$ & $6.87 \pm 0.03 \mathrm{e}$ & $5.58 \pm 0.50 \mathrm{~b}$ \\
\hline 0.006 & $123.50 \pm 0.10 \mathrm{c}$ & $28.17 \pm 0.15 \mathrm{a}$ & $76.40 \pm 0.10 \mathrm{c}$ & $143.87 \pm 1.19 \mathrm{c}$ & $6.61 \pm 0.01 \mathrm{~d}$ & $9.50 \pm 0.08 \mathrm{c}$ \\
\hline 0.009 & $173.63 \pm 0.12 \mathrm{~d}$ & $28.17 \pm 0.21 \mathrm{a}$ & $116.40 \pm 0.00 \mathrm{~d}$ & $192.70 \pm 1.40 \mathrm{~d}$ & $6.39 \pm 0.07 \mathrm{c}$ & $13.58 \pm 0.50 \mathrm{~d}$ \\
\hline 0.012 & $223.93 \pm 0.06 \mathrm{e}$ & $28.27 \pm 0.15 \mathrm{a}$ & $156.63 \pm 0.06 \mathrm{e}$ & $263.47 \pm 0.67 \mathrm{e}$ & $6.14 \pm 0.04 \mathrm{~b}$ & $17.55 \pm 0.02 \mathrm{e}$ \\
\hline 0.015 & $281.67 \pm 3.65 \mathrm{f}$ & $28.40 \pm 0.36 \mathrm{a}$ & $187.63 \pm 15.79 \mathrm{~d}$ & $314.23 \pm 0.06 \mathrm{f}$ & $5.72 \pm 0.18 \mathrm{a}$ & $21.58 \pm 0.50 \pm \mathrm{f}$ \\
\hline
\end{tabular}

Each data is expressed as mean \pm standard deviation $(n=3)$; Different alphabets along the column indicate significant difference $(P<0.05)$ according to Waller Duncan test statistics.

Table2: Mortality rate of Heterobranchus bidorsalis fingerlings exposed to cassava mill effluents.

\begin{tabular}{|c|c|c|c|c|c|}
\hline \multirow{2}{*}{ Concentration, ml/L } & \multicolumn{5}{|c|}{ Hours } \\
\hline & $\mathbf{0}$ & 24 & 48 & 72 & 96 \\
\hline 0.000 & $0.00 \pm 0.00$ & $0.00 \pm 0.00 \mathrm{a}$ & $0.00 \pm 0.00 \mathrm{a}$ & $2.77 \pm 4.81 \mathrm{a}$ & $5.55 \pm 4.81 \mathrm{a}$ \\
\hline 0.003 & $0.00 \pm 0.00$ & $8.33 \pm 0.00 \mathrm{ab}$ & $19.45 \pm 4.81 b$ & $27.78 \pm 4.81 b$ & $41.67 \pm 0.00 \mathrm{~b}$ \\
\hline
\end{tabular}


Annals of Reviews and Research

\begin{tabular}{|c|c|c|c|c|c|}
\hline 0.006 & $0.00 \pm 0.00$ & $13.89 \pm 4.82 \mathrm{~b}$ & $19.45 \pm 4.81 \mathrm{~b}$ & $44.45 \pm 4.81 \mathrm{c}$ & $58.33 \pm 0.00 \mathrm{c}$ \\
\hline 0.009 & $0.00 \pm 0.00$ & $16.67 \pm 8.34 \mathrm{~b}$ & $25.00 \pm 0.00 \mathrm{~b}$ & $52.78 \pm 4.81 \mathrm{c}$ & $69.45 \pm 4.81 \mathrm{~d}$ \\
\hline 0.012 & $0.00 \pm 0.00$ & $27.78 \pm 4.81 \mathrm{c}$ & $41.67 \pm 8.34 \mathrm{c}$ & $63.89 \pm 4.82 \mathrm{~d}$ & $77.78 \pm 4.81 \mathrm{~d}$ \\
\hline 0.015 & $0.00 \pm 0.00$ & $30.55 \pm 4.81 \mathrm{c}$ & $50.00 \pm 8.33 \mathrm{c}$ & $75.00 \pm 8.33 \mathrm{e}$ & $91.68 \pm 8.34 \mathrm{e}$ \\
\hline
\end{tabular}

Each data is expressed as mean \pm standard deviation $(n=3)$; Different alphabets along the column indicate significant difference $(P<0.05)$ according to Waller Duncan test statistics.

Table2 presents mortality rate in Heterobranchus bidorsalis fingerlings exposed to cassava mill effluents. There was no mortality at 0hours of exposure. Mortality were in dose depended manner. There was significant variations $(\mathrm{P}<0.05)$ among the various concentration for each of the time interval. At 96 hours the mortality rate were $39.55 \%, 50.00 \%, 75.00 \%$ and $91.68 \%$ for $0.000 \mathrm{ml} / \mathrm{L}, 0.003 \mathrm{ml} / \mathrm{L}, 0.006 \mathrm{ml} / \mathrm{L}, 0.012 \mathrm{ml} / \mathrm{L}$ and $0.015 \mathrm{ml} / \mathrm{L}$. The findings of this study showed that the cassava mill effluents are toxic to the fishes. Several factors such as acidity and cyanide content of cassava may have contributed to the toxicity level [13]. Studies have shown that $\mathrm{pH}$ of 6.5 - 9.0 [37-39] is ideal for aquaculture. Bhatnagar and Devi (2013) also provided a stricter limit of $7.0-8.5$. Due to the effects of the effluents the acidity of the aquarium water decreased (tending toward acidity). This therefore suggests the effect of acidification on the Heterobranchus bidorsalis fingerlings.

Adeyemo (2005) described cyanide as a potent respiratory poison that has adverse effect on aquatic organisms such as fishes. The author also reported that cyanide at even low concentration could elicit physiological and pathological effects in fishes. Therefore, cyanide causes stress in fishes. Cassava mill effluents in aquatic ecosystem could affect oxygen content in the water which therefore affects the rate of respiration among fishes, and ultimately contributing to mortality rate $[40,13]$. In addition, Olufayo and David (2016) reported that variation in the oxygen consumption due to the effect of cassava mill effluents on exposed fishes is associated with impaired oxidative metabolism and respiratory stress.

\section{Conclusion}

In some coastal areas in Bayelsa state, cassava processing mill are found close to the aquatic ecosystem. The wastewater often drains into nearby pit and surface water itself. The results of this study showed that cassava mill effluents induce mortality in fingerlings of Heterobranchus bidorsalis even at low concentration. Therefore, there is the need to located cassava processing mills far from surface water resources.

\section{References}

1. Izah SC, Bassey SE, Ohimain EI (2017) Assessment of heavy metal in cassava mill effluent contaminated soil in a rural community in the Niger Delta region of Nigeria. EC Pharmacology and Toxicology 4(5): 186-201.

2. Izah SC, Bassey SE, Ohimain EI (2017) Geo-accumulation index, enrichment factor and quantification of contamination of heavy metals in soil receiving cassava mill effluents in a rural community in the Niger Delta region of Nigeria. Molecular Soil Biology 8(2): 7-20.

3. Izah SC, Bassey SE, Ohimain EI (2017) Assessment of pollution load indices of heavy metals in cassava mill effluents contaminated soil: a case study of small-scale cassava processing in a rural community in the Niger Delta region of Nigeria. Bioscience Methods 8(1): 1-17.

4. Izah SC, Bassey SE, Ohimain EI (2017) Changes in the treatment of some physico-chemical properties of cassava mill effluents using Saccharomyces cerevisiae. Toxic 5(4): 28.

5. Izah SC, Bassey SE, Ohimain EI (2017) Removal of Heavy Metals in Cassava Mill Effluents by Saccharomyces cerevisiae isolated from Palm Wine. MOJ Toxicology 3(4): 00058.

6. Izah SC, Bassey SE, Ohimain EI (2017) Cyanide and Macro-Nutrients Content of Saccharomyces cerevisiae Biomass Cultured in Cassava Mill Effluents. International Journal of Microbiology and Biotechnology 2(4): 176-180.

7. Izah SC, Bassey SE, Ohimain EI (2017) Amino acid and proximate composition of Saccharomyces cerevisiae biomass cultivated in Cassava mill effluents. Molecular Microbiology Research 7(3): 20-29.

8. Izah SC, Bassey SE, and Ohimain EI (2017) Assessment of Some Selected Heavy Metals in Saccharomyces cerevisiae Biomass Produced from Cassava Mill Effluents. EC Microbiology 12(5): 213223.

9. Izah SC, Bassey SE, Ohimain EI (2018) Ecological risk assessment of heavy metals in cassava mill effluents contaminated soil in a rural community in the Niger Delta Region of Nigeria. Molecular Soil Biology 9(1): 1-11.

10. Izah SC, Bassey SE, Ohimain EI (2018) Impacts of Cassava mill effleunts in Nigeria. Journal of Plant and Animal Ecology 1(1): 14-42.

11. Izah SC, Aigberua AO (2017) Assessment of Microbial Quality of Cassava Mill Effluents Contaminated Soil in a Rural Community in the Niger Delta, Nigeria. EC Microbiology 13(4): 132-140.

12. Izah SC (2018) Estimation of Saccharomyces cerevisiae Biomass Cultured in Cassava Mill Effluents. Environmental Analysis and Ecology studies 2(5): EAES.000547.

13. Izah SC (2018) Estimation of Potential Cassava Mill Effluents Discharged into Nigerian Environment. Environmental Analysis and Ecology studies 2(5): EAES.000550.

14. Kigigha LT, Izah SC and Kpea TB (2015) Microbiological quality of fermented Cassava Flakes (Gari) sold in Yenagoa, Metropolis, Nigeria. Bulletin of Advanced Scientific Research 1(7): 157-160.

15. Kigigha LT, Nyenke P, Izah SC (2018) Health risk assessment of selected heavy metals in gari (cassava flake) sold in some major markets in Yenagoa metropolis, Nigeria. MOJ Toxicol. 4(2):47-52.

16. Izah SC, Ohimain EI (2015) Bioethanol production from cassava mill effluents supplemented with solid agricultural residues using baker's yeast [Saccharomyces cerevisiae]. J Environ Treat Techniq 3(1): 47-54.

17. Izah SC (2016) Bioethanol production from cassava mill effluents supplemented with oil palm chaff, empty fruit bunch and cassava peels using Saccharomyces cerevisiae. M.Sc. thesis submitted to School of Post Graduate Studies, Niger Delta University, Wilberforce Island, Nigeria, 113.

18. Inyang IR, Ajimmy R, Izah SC (2017) Organosomatic index and behavioral response of Heterobranchus bidorsalis exposed to rhonasate 360SL containing glyphosate (isopropylamine salt glycine). ASIO J Microbiol Food Sci Biotechnol Innov 3(1): 4-8. 
19. Inyang IR, Izah SC, Johnson DT, Ejomarie OA (2017) Effects of Lambda cyhalothrin on some electrolytes and metabolites in organs of Parpohiocephalus obscurus. Biotechnol Res 3(1): 6-10.

20. Inyang IR, Ollor AO, Izah SC (2017) Effect of Diazinon on Organosomatic Indices and Behavioural Responses of Clarias gariepinus (a Common Niger Delta Wetland Fish). Greener J Biol Sci 7(2): 015- 019.

21. Inyang IR, Seiyaboh EI, Job UB (2017) Condition Factor, Organosomatic Indices and behavioural Abnormalities of Clarias gariepinus exposed to Lambda Cyhalothrin. Greener J Life Sci 4 (1): 001-005.

22. Olufayo MO, David OT (2016) The effect of cassava mill effluent on histology of Clarias gariepinus juveniles. Revue Scientifique et Technique Forêt et Environnement du Bassin du Congo7: 10-17.

23. Inyang IR, Akio K, Izah SC (2016) Effect of dimethoate on lactate dehydrogenase, creatinine kinase and amylase in Clarias lazera. Biotechnol Res 2(4): 155-160.

24. Inyang IR, Kenobi A, Izah SC (2016) Effect of dimethoate on some selected metabolites in the brain, liver and muscle of Clarias lazera. Sky J Biochem Res 5(4): 63-68.

25. Inyang IR, Obidiozo OZ, Izah SC (2016) Effects of Lambda cyhalothrin on protein and Albumin content in the kidney and liver of Parpohiocephalus obscurus. EC Pharmacol Toxicol 2(3): 148-153.

26. Inyang IR, Okon NC, Izah SC (2016) Effect of glyphosate on some enzymes and electrolytes in Heterobranchus bidosalis (a common African catfish). Biotechnol Res 2(4):161-165.

27. Inyang IR, Thomas S, Izah SC (2016) Activities of electrolytes in kidney and liver of Clarias gariepinus exposed to fluazifop-p-butyl. J Biotechnol Res 2(9): 68-72.

28. Inyang IR, Thomas S, Izah SC (2016) Evaluation of Activities of Transferases and Phosphatase in Plasma and Organs of Clarias gariepinus Exposed to Fluazifop-p-Butyl. J Environ Treat Techniq 4(3): 94-97.

29. Ogamba EN, Izah SC, Nabebe G (2015) Effects of 2, 4-Dichlorophenoxyacetic acid on the electrolytes of blood, liver and muscles of Clarias gariepinus. Nig J Agriculture Food Environ 11(4): 23-27.

30. Ogamba EN, Izah SC, Numofegha K (2015) Effects of dimethyl 2, 2-dichlorovinyl phosphate on the sodium, potassium and calcium content in the kidney and liver of Clarias gariepinus. Res J Pharmacol Toxicol 1(1): 27-30
31. Olufayo MO, David OT (2016) The effect of cassava mill effluent on histology of Clarias gariepinus juveniles. Revue Scientifique et Technique Forêt et Environnement du Bassin du Congo 7: 10-17.

32. Adewoye SO, Sawyeer HO and Opasola OA (2016) Studies on Cassava Mill Effluent and its Toxicological Impact using Histopathological Technique. International Journal of Innovative Environmental Studies Research 4(3): 24-33.

33. SO Adewoye, Fawole O0, Owolabi OD, Omotosho JS (2005) Toxicity of cassava wastewater effluents to African catfish: Clarias gariepinus (Burchell, 1822). Ethiopian J Science 28(2): 189-194.

34. Olayinka AS (2013) Assessment of toxic potentials of cassava effluent on Clarias gariepinus. International Journal of Agricultural Science and Research 3(3): 157-160.

35. Adeyemo OK (2005) Haematological and histopathological effects of cassava mill effluent in Clarias gariepinus. African Journal of Biomedical Research 8 (3): 179-183.

36. Ariyomo TO, Jegede T, Adeniran AF, Omobepade BP (2017) Toxicity of Cassava Effluents to Catfish, Clarias gariepinus, and the Effect on Some Target Organs. Annals of Aquaculture and Research 4(2): 1034.

37. Asogwa CN, Ezenwajiaku FO, Okolo CA, Ekeh FN, Nwibo DD, et al. (2015) Behavioural and biochemical responses of juvenile catfish (Clarias gariepinus) exposed to graded concentrations of cassava waste water. Animal Research International 12(1): 2136-2142.

38. Boyd CE (1979) Water quality in warmwater fish ponds. Auburn University Agricultural Experiment Station, Auburn, Alabama, USA.

39. Okomoda VT, Ataguba GA, Ayuba VO (2013) Hematological Response of Clarias gariepinus Fingerlings Exposed to Acute Concentrations of Sunsate ${ }^{8}$. Journal of Stress Physiology and Biochemistry 9(2): 271278.

40. Oloruntuyi 00, Mulero O, Odukale B (1993) The effects of two pesticides on Clarias gariepinus. In: $10^{\text {th }}$ Annual Conference of the Fisheries Society of Nigeria (FISON), 16-20 November 1992, Abeokuta, Nigeria, pp. 173-177.

41. Oyoroko E, Ogamba EN (2017) Toxicity of Detergent Containing Linear Alkyl benzene Sulphonate on Some Commonly Cultured Fish Species in the Niger Delta. Journal of Environmental Treatment Techniques 5(2): 72-77.

42. Bhatnagar A, DeviP (2013) Water quality guidelines for the management of pond fish culture. International Journal of Environmental Sciences 3(6): 1980-2009.

\section{Your next submission with Juniper Publishers will reach you the below assets}

- Quality Editorial service

- Swift Peer Review

- Reprints availability

- E-prints Service

- Manuscript Podcast for convenient understanding

- Global attainment for your research

- Manuscript accessibility in different formats

( Pdf, E-pub, Full Text, Audio)

- Unceasing customer service

Track the below URL for one-step submission https://juniperpublishers.com/online-submission.php 